\title{
KORRÓZIÓÁLLÓSÁG MINŐSÍTÉSE KÉPELEMZŐ SZOFTVER ALKALMAZÁSÁVAL
}

\section{CORROSION RESISTANCE QUALIFICATION BY APPLICATION OF IMAGE ANALYSIS SOFTWARE}

\author{
Bagyinszki Gyula ${ }^{1}$, Losonci Kálmán ${ }^{2}$ \\ I'Óbudai Egyetem, Bánki Donát Gépész és Biztonságtechnikai Mérnöki Kar, \\ Magyarország, 1081 Budapest, Népszínház u.8, bagyinszki.gyula@bgk.uni-obuda.hu \\ ${ }^{2}$ ÉLINVEST Kft., Magyarország, 1184 Budapest, Lakatos u. 61-63, \\ losoncikalman@gmail.com
}

\begin{abstract}
In this paper we investigate corrosion behaviour according to an example of the surface treated base metal and TIG-welded joints of X2CrNi18-9 austenitic stainless steel. For the evaluation of the corrosion tests we used not traditional methodologies.

Keywords: pitting corrosion, stainless steel, TIG welding, ferric chloride, image analysis

\section{Összefoglalás}

Cikkünkben a X2CrNi18-9 anyagminőségü ausztenites korrózióálló acél példája kapcsán vizsgáljuk a felületkezelt alapanyag és a TIG-eljárásváltozatokkal hegesztett kötések korróziós viselkedését. Ezen korróziós vizsgálatok kiértékeléséhez olyan metodikát alkalmazunk, amely eltér az eddig használt módszerektől.
\end{abstract}

Kulcsszavak: pitting-korrózió, korrózióálló acél, TIG hegesztés, vas-klorid, képelemzés

\section{A korrózió érintett problémaköre}

A hegesztési hőfolyamat során, a korrózióálló acélok hegesztett varrataiban, illetve azok hőhatásövezetében megváltozik a szövetszerkezet, az ötvözőelem-eloszlás módosul, krómban elszegényedett zónák jönnek létre, a passziváló ötvözőtartalom a rezisztencia határ szintje alá kerül, s ezzel gyengül a korrózióállóság. Így az autogén (hozaganyag nélküli), illetve alapanyaggal megegyező hozaganyagú hegesztésnél a korrózióállóság nem éri el azt a szintet, mint egy magasabb Cr, Ni és Mo tartalmú hozaganyag használatakor.
A varratban és környékén mikroszegregáció, szekunder fáziskiválás, ötvözők egyenlőtlen eloszlása, rekrisztallizációs szemcsedurvulás, ötvöző kiégés mehet végbe. A kötés korrózióálló-ságát befolyásolják még a hőkezelés, az üzemi hőmérséklet, a maradó feszültségek, üzemi feszültségek is. A korrózió megjelenési formái ausztenites korrózióálló acélok hegesztett kötéseiben: szemcseközi korrózió, szegregációs korrózió, pitting- és réskorrózió, feszültségkorrózió lehetnek. Ezek közül a továbbiakban a pittingkorrózióval foglalkozunk. 


\section{Pitting-korrózió és vizsgálata}

A varratban és höhatásövezetében - ahol az ötvözőtartalom lecsökkent - elöfordulhatnak pitting-korróziós bemaródások, melyek általában kloridos közegben jelentkeznek:

- hozaganyag nélküli hegesztés esetén,

- alacsonyabb Mo-tartalmú ötvözeteknél,

- alapanyaggal megegyezö összetételü hozaganyag használata okán,

- ha nagy hőbevitelü hegesztést követően eldurvult szövetszerkezet alakul ki.

A pitting-korróziós ellenállás egyenérték vagy PREN (Pitting Resistance Equivalent Number) olyan mutatószám, ami korrózióálló acélok kloridos közeggel szemben mutatott pitting-korróziós ellenállását fejezi $\mathrm{ki}:$ PREN $=1 \cdot \mathrm{Cr} \%+$ $3,3 \cdot \mathrm{Mo} \%+16 \cdot \mathrm{N} \%$. A magasabb PREN érték jobb ellenállást jelent és a képletböl adódik, hogy a Mo hatékonyabban növeli a pitting korróziós ellenállást, mint a $\mathrm{Cr}$. A króm viszont nélkülözhetetlen a passzív oxidfilm kialakulásához.

A vizsgálat során egy erösen savas környezetet szimulálnak. Az alkalmazott közeg 6\%-os $\mathrm{FeCl}_{3}$ oldat, melyben $24 \ldots 72$ óráig tartják a próbatest(ek)et. A vizsgálatot környezeti vagy $50{ }^{\circ} \mathrm{C}$-os hőmérsékleten végzik. A vizsgálat befejeztével meghatározzák a tömegveszteséget, majd a megtisztított felületen vizsgálják a pittingkorróziós nyomok méretét, alakját és sürüségét (eloszlását).

\section{Kísérleti és minősítési metodika}

Célunk a ,nyers” ill. a felületkezelt alap-anyag és a különböző TIGeljárásváltoza-tokkal, technológiai paraméterekkel elkészült hegesztett kötések pitting-korróziós viselkedésének összehasonlítása. A korróziós vizsgálatokhoz 40 x 70 mm-es darabokat (középen a varrattal) munkáltunk ki gépi lemezollóval, hegesztett kötésenként egyet-egyet.
További próbadarabokonen különböző, a rozsdamentes acélokhoz gyakran használt felületcsiszolási eszközöket használtunk. Ezen előkészítés után a korróziós vizsgálat rögtön megkezdödött, az elvékonyított oxidfilmnek nem volt ideje teljesen visszaépülni.

Korrozív közegként 6\%-os vasklorid (III) oldatot használtunk, az ASTM International G46-94 szabvány ajánlása szerint. A próba-testek $20 \pm 2{ }^{\circ} \mathrm{C}$-on, 72 óráig voltak az oldatban. A kiértékelés viszont nem az ASTM G48-as szabvány szerint történt, hanem újszerü megközelítéssel éltünk és képelemző szoftvert vettünk igénybe. Az oldatból kivett próbadarabokat mechanikai és vegyi úton megtisztítottuk, hogy a korró-ziós nyomok láthatóvá váljanak (1. ábra).

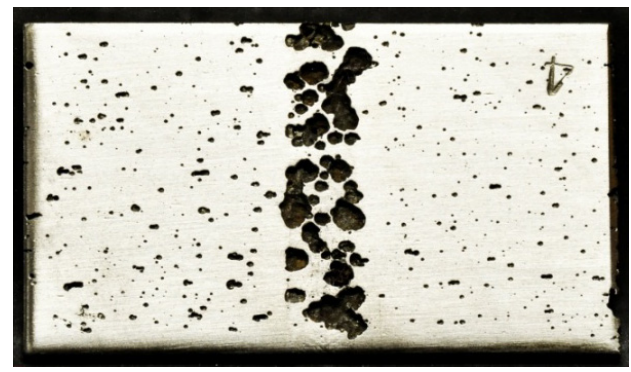

1. ábra. Hozaganyag nélkül hegesztett kötés korróziója

A varratok koronaoldalán, azokkal párhuza-mosan mértük a bemaródások átlagos felületét, százalékos eloszlását, külön a hőhatásövezeten belül és külön azon kívül. A próbadarabokról nagy felbontású digitális fényképeket készítettünk, melyeket tovább javítottunk a kontraszt kiemelésével. A teljes kontrasztosság (csak fekete és fehér képpontok) elérése lényeges szempont a mérési pontosság javításához. A kontrasztkiemelés után képelemző szoftverrel „mértük” a sötét/világos képpont-arányt a varratvonallal párhuzamosan (2. ábra). 


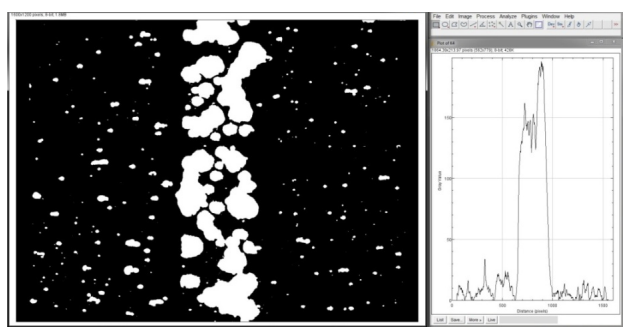

2. ábra. Szürkeárnyalat számitás képelemzővel

A képeket az ImageJ nevü szoftver PlotProfile parancsával elemeztük. A program az y tengely mentén átlagolja a szürkeárnyalat értékét. A szürkeárnyalat értékei RGB színkódban 0-255 között változnak a feketétöl a fehérig. Ahhoz, hogy százalékos értéket kapjunk, át kell váltani a szürkeárnyalat értékeit $(256=100 \%)$. Mivel eredetileg a fekete jelentené a $0 \%$-ot, ezért a kép inverzét kell képeznünk. Az eredményeket diagramban ábrázoltuk, az x tengelyen a varrattól mért távolságot adtuk meg milliméterben, az y tengelyen a korrodálódott felületarányt százalékban.

A kiválasztott képen Threshold paranccsal körvonalaztunk minden egyes foltot, majd az Analyze Particles paranccsal megmértük a felületüket. A program automatikusan sorszámozza a foltokat és táblázatba rendezi a felületük méretével együtt. A program a kiválasztott körvonalokon belüli képpontok számát adja meg, amit a felbontás ismeretében $\mathrm{mm}^{2}$-re kell váltani.

A „nyersen” hagyott próbadarab korróziója elhanyagolható, viszont az erősebb mechanikai felületkezelés erősebb korróziót okozott (3. ábra), ami összefüggésbe hozható az oxidfilm elvékonyításának mértékével.

A réz alátétlemezes autogén hegesztésủ kötések $(1,2)$ korróziója a varrat középtengelyén a legerősebb, az argonos gyökvédelemmel készültek $(3,4)$ nem mutatnak lényeges különbséget (4. ábra). Minden esetben már a beolvadási zónán kívülről megindul a korrózió felerősödése, ami a varratfém ötvözötartalmának változásával hozható összefüggésbe.

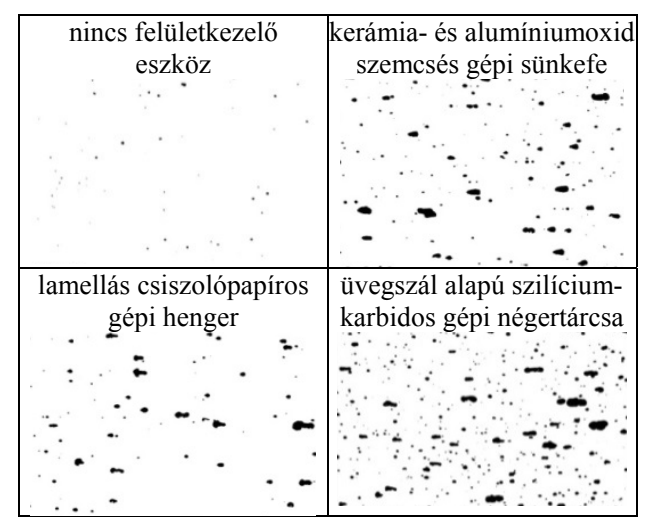

3. ábra. Felületkezelt darabok korróziója
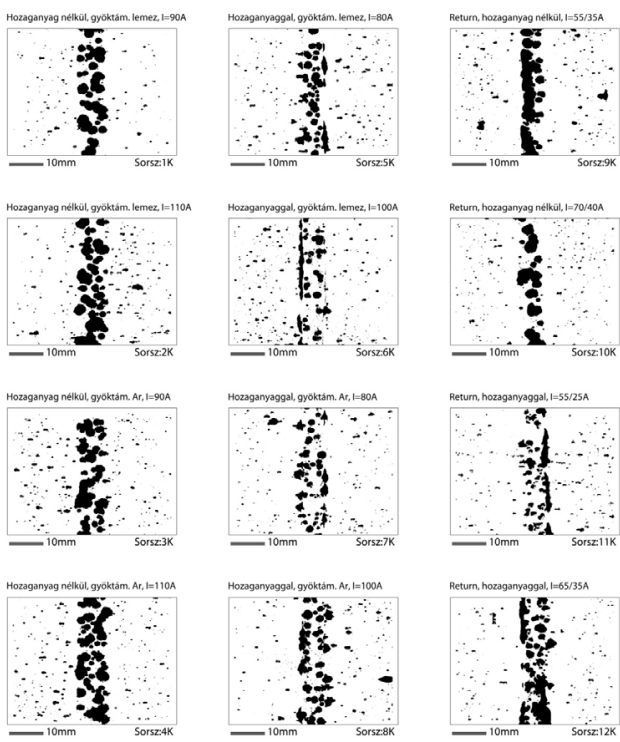

4. ábra. Pitting-korrózió
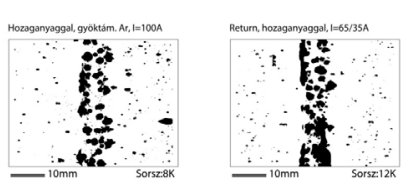

koronaoldalán

varratok

A hozaganyaggal végzett egyoldali hegesztett kötések $(5,6,7,8)$ korróziója szintén a beolvadási vonalban a legerösebb, de a korrózió csúcsértékei eltolódtak a beolvadási vonal széle felé, ahol az alapanyag részlegesen átolvadt (4. ábra). A 
hozaganyag $\mathrm{Cr}$-tartalma nem nagyobb, mint az alapanyagé, de tartalmaz Mo-t is, ami tovább növeli a pitting-korróziós ellenállást: $\mathrm{PREN}_{\text {alapanyag }}=18,3 ; \mathrm{PREN}_{\text {hozaganyag }}=26,5$.

„Return” (két oldalról egyidőben hegesztő) eljárásváltozattal készített hozaganyag nélküli próbadarabok $(9,10)$ korróziója a varrat középvonalán a legnagyobb. Hozaganyag alkalmazás (11, 12) után hasonló eredményeket kaptunk, mint az egyoldali hegesztések esetében: varratfém viszonylag alacsony korróziója, beolvadási vonal szélénél „késél” korrózió. Az 5. ábra a vizsgálati eredmények közül a „Return” hegesztések korróziós görbéit ábrázolja.

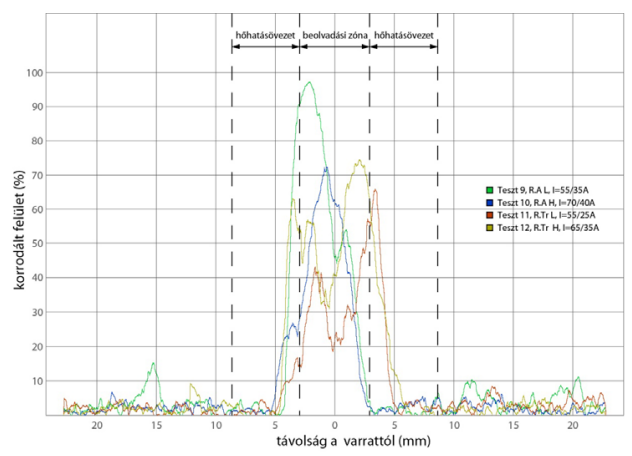

5. ábra. „Return” hegesztések korróziós görbéi

Az egyoldali autogén hegesztés beolvadási vonalának korróziója a legmagasabb és szélesen kiterjed a varraton kívül is. A kétoldali „Return” hegesztéseknél csak a beolvadási vonalban erösödik fel a korrózió, ami a keskenyebb hőhatásövezet eredménye.

A hozaganyagos egyoldali hegesztéseknél a beolvadási zóna korróziója alacsonyabb és a varrat középvonalán a legkisebb, de ugrásszerüen növekvő korrózió jellemzi a beolvadási vonal széleit. $\mathrm{Az}$ 1. táblázat összefoglalja a pittingkorróziós nyomok adatait.
1. táblázat. Hegesztett kötések pitting-korróziós adatai

\begin{tabular}{|c|c|c|c|c|c|c|c|c|}
\hline \multirow[b]{2}{*}{ 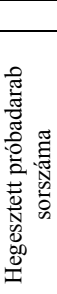 } & \multicolumn{4}{|c|}{ Höhatásövezetben } & \multicolumn{4}{|c|}{ Höhatásövezeten kívül } \\
\hline & 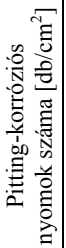 & 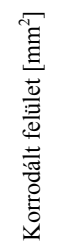 & 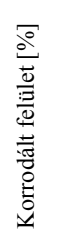 & 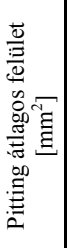 & 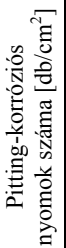 & 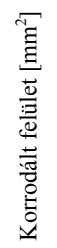 & 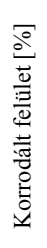 & 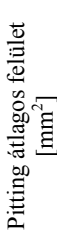 \\
\hline 1. & 12,8 & 161,1 & 31,4 & 2,4 & 27,1 & 16,0 & 1,4 & 0,1 \\
\hline 2. & 14,2 & 194,9 & 37,9 & 2,6 & 39,9 & 34,6 & 2,9 & 0,2 \\
\hline 3. & 14,8 & 165,4 & 32,2 & 2,2 & 51,4 & 34,2 & 2,9 & 0,1 \\
\hline 4. & 14,2 & 200,1 & 38,9 & 2,7 & 54,1 & 35,4 & 3,0 & 0,1 \\
\hline 5. & 22,8 & 129,3 & 25,2 & 1,1 & 39,7 & 31,2 & 2,6 & 0,2 \\
\hline 6. & 28,4 & 112,3 & 21,9 & 0,8 & 78,6 & 37,3 & 3,2 & 0,1 \\
\hline 7. & 23,2 & 108,8 & 21,2 & 0,9 & 40,5 & 30,0 & 2,5 & 0,1 \\
\hline 8. & 27,2 & 151,4 & 29,5 & 1,1 & 41,3 & 33,5 & 2,8 & 0,2 \\
\hline 9. & 12,1 & 160,9 & 31,3 & 2,6 & 56,8 & 41,0 & 3,5 & 0,1 \\
\hline 10. & 14,0 & 117,8 & 22,9 & 1,6 & 56,2 & 22,6 & 1,9 & 0,1 \\
\hline 11. & 19,9 & 111,2 & 21,6 & 1,1 & 42,4 & 27,2 & 2,3 & 0,1 \\
\hline 12. & 21,0 & 143,0 & 27,8 & 1,3 & 35,4 & 22,0 & 1,9 & 0,1 \\
\hline
\end{tabular}

\section{Következtetések}

Noha az alapanyag ellenálló, hegesztés ill. felületkezelés alkalmazása miatt a korróziós ellenállás jelentősen romlik. A hőhatásövezeten belül autogén eljárásnál nagyobb felületű pitting-nyomok képződtek, mint a hozaganyagosak esetében.

\section{Szakirodalmi hivatkozások}

[1] A. J. Sedriks: Corrosion Resistance of Stainless Steels and Nickel Alloys, 2003.

[2] J. R. Davis: Corrosion of Weldments, ASM International Materials Park, Ohio, 2006.

[3] Haraszti Ferenc, Kovács Tünde: Kontakt korrózió vizsgálata, Paper 59 Proceedings of 8th International Engineering Symposium at Bánki (ISBN: 978-615-5460-95-1), 2016

[4] Stephen D. Cramer, Bernard S. Covino: ASM Handbook - Corrosion: Fundamentals, Testing and Protection, 2003.

[5] ASTM G 46-94 szabvány: Standard Guide for Examination and Evaluation of Pitting Corrosion, 2005

[6] Nickel Development Institute: Guidelines for the welded fabrication of nickel-containing stainless steels for corrosion resistant services - Series No. 11007, 1994. 